\title{
Between the Democratisation of International Relations and Status Quo Politics: Russia's Foreign Policy towards the Iranian Nuclear Programme ${ }^{1}$
}

\author{
Moritz Pieper
}

\begin{abstract}
This article sheds light on Russia's foreign policy towards the Iranian nuclear programme and analyses to what extent Russia's Iran policies are indicative of a security culture that resists hegemony. Following a two-level model between a discursive and a behavioral level of foreign policy, it will be shown how Moscow advocates a non-hegemonic security culture discursively, but still displays a level of behavioral convergence with hegemonic power structures. Process-tracing Russia's positioning on the Iranian nuclear dossier as from the disclosure of Iran's nuclear programme in 2002, the article carves out Russian normative conceptions in international relations and material considerations that let Russia partially fall short of acting upon its own discourse. It will be argued that Russian Iran policy is the outcome of a balancing act between resistance to hegemony and hegemonic accommodation.
\end{abstract}

\section{Introduction}

On 2 April 2015, a political framework agreement was reached over Iran's controversial nuclear programme. This was a first step in ending the more than decade-old odyssey of nuclear diplomacy with Iran. Following an unprecedented Iranian diplomatic outreach since the late summer 2013, the six world powers negotiating with Iran (the five permanent UN Security Council members plus Germany) had managed to agree on a common approach to seize the momentum of optimism generated by the election of Hassan Rouhani in June 2013.

\footnotetext{
${ }^{1}$ For their helpful comments on earlier versions of this article, I am grateful to Dr. Tom Casier and Dr. Tugba Basaran. Versions of this article have been presented at conferences at the Russian Academy of Sciences, Moscow, in April 2013, and at the University of West Bohemia, Plzeň, in April 2015.
} 
A first interim agreement with Iran was reached on 24 November 2013. This display of 'P5+1' consensus had not always been the case. The political crisis over the Iranian nuclear programme was never only a dispute between Iran and an ill-defined 'international community', but reveals a much deeper-seated contention about the coexistence between 'the West' and other powers that challenge an essentially U.S.-dominated world order and its political paradigms. In the negotiation format that emerged when Iran's nuclear file was referred to the United Nations Security Council (UNSC) in March 2006, cleavages became apparent between the positions of Western governments and those of Russia and China, with the latter giving the impression that Beijing tended to follow Moscow's positioning and voting pattern. ${ }^{1}$

Against the backdrop of the centrality of Russia for any resolution to the Iranian nuclear file, this article analyses to what extent Russian foreign policy towards Iran's nuclear programme is illustrative of a security culture that resists hegemony. Proceeding from a neoGramscian understanding of hegemony, Russia's Iran policy will be analysed through the prism of Russia's interaction with the material, ideational, and institutional dimensions of hegemonic structures (see Cox, 1981, 139).

In light of Russia's self-understanding of its position in the international system of states, it thereby disentangles Russian foreign policy toward the Iranian nuclear programme as the outcome of a delicate balancing act between strategic engagement with 'the West' and adherence to foreign policy norms that partially clash with Western interests. The argument presented here thus nuances the idea that Russia acts as a revisionist state, aiming to challenge U.S.-dominated paradigms in international relations. It will be argued, instead, that Russian foreign policy towards Iran is the outcome of a balancing act between resistance to hegemony and hegemonic accommodation (cf. also Pieper 2014). Not least because of traumatized USIranian relations and the centrality of the US in Iranian foreign policy discourse, Washington holds considerable sway over Iran's nuclear future. But also on a structural level, the 
omnipresence of US financial power in international governance and the extent to which this particular leverage shapes policy formulation of other actors creates what in this article will be called 'hegemonic structures'. These structures have met criticism and outright rejection by a range of actors, including Iran.

A first section process-traces the disagreements between Russia and its Western counterparts over diplomatic approaches to Iran's nuclear programme following the latter's disclosure in 2002 as an illustration of Western-Russian normative disagreements and Russia's reaction to an emerging U.S. securitisation of the Iranian nuclear issue. A second section analyses Russia's stance on unilateral and international sanctions on Iran against the background of Russo-Iranian bilateral relations, Russo-American relations and Moscow's understanding of the functioning of international security governance. This is an important analytical step for an examination of Russia's understanding of legitimacy in international politics. 'Norms and values' are understood here as concrete convictions and conceptions (such as 'sovereignty' or 'non-interference'), while 'rules and models' relate to the broader macro-structure that regulates the way these norms and values are communicated, applied, or changed (see Katzenstein, 1996, 21). Especially the sanctions issue serves as an illustrative application of these concepts: If Russia accepts and approves international sanctions as mandated by the United Nations Security Council, it conveys a basic acceptance of the rules of the U.N. system. An analysis of Russia's understanding of unilateral sanctions that are adopted and implemented without involving U.N. procedures conveys an insight into Russia's normative conceptions that may or may not be different from those powers adopting such sanctions.

On the basis of this analysis, the final two sections show how a two-level distinction between a discursive and a behavioral dimension of foreign policy applies to Russia's Iran policy. These sections build on the preceding analysis of Russia's sanctions policy and Iran diplomacy and identify material as well as social factors in Russia's Iran policy that make up 
a complex web of foreign policy motivations which in this article is captured by a two-level model to understand the nexus between security culture and the degree of resistance to hegemony. Russian foreign policy discourse on Iran's nuclear programme and on Western and especially U.S. approaches to Iran's nuclear programme will be contrasted with Russia's foreign policy behavior that may be in contradiction with a security culture Russia itself advocates for. Resistance to hegemony is understood as disagreements with hegemonic structures. This disagreement necessarily is captured in degree and is composed of diverse discursive as well as behavioral elements: A public advocacy for norms alternative to those sustained by hegemonic forces can be paralleled by a foreign policy behavior that falls short of acting upon this discourse. Making sense of such a variation in 'compliance' weaves together the concepts of norm divergence and rule convergence and allows an answer to the question how Russia's foreign policy towards Iran's nuclear programme is illustrative of a security culture that resists hegemony. The research method comprises qualitative data analysis, complemented by semi-structured elite interviews with experts and decision-makers.

\section{Russia's Foreign Policy towards Iran following the Revelation of the Iranian Nuclear Programme in 2002: Reacting to U.S. Securitisations and Discursive Resistance}

With the revelation of an Iranian enrichment facility in Natanz and a heavy-water plant under construction at Arak, hitherto undeclared to the IAEA and thus in breach of Iran's Safeguards Agreements, Russian nuclear cooperation with Iran suddenly appeared in a disconcerting light (Lata and Khlopkov 2003). ${ }^{2}$ Russo-Iranian nuclear cooperation had started in September 1994 when a protocol was signed between the Russian Atomic Energy Minister, Viktor Mikhailov, and the president of the Atomic Energy Organisation of Iran (AEOI), Reza Amrollahi, in which the Russians expressed their willingness to complete the 1000-MW power reactor at 
Bushehr worth 800 million U.S. dollars. Bushehr was Iran's only nuclear power plant project that had been started by German Kraftwerk Union AG in 1970 (Yurtaev, 2005, 107), but was abandoned in the wake of the Islamic Revolution (Orlov and Vinnikov, 2005, 50). Unable to get nuclear technology from its former European partners that had cooperated with Iran in the starting phases of the Iranian nuclear programme under the Shah in the 1960s and 1970s, ${ }^{3}$ Iran had turned to China and the USSR (with Russia succeeding the latter). As from the mid-1990s and despite U.S. pressure, Russia had become Iran's nuclear partner (cf. also Sarukhanyan, 2006, 88-108).

Against the backdrop of the uranium fuel sales for the construction of Bushehr, Putin appeared pugnacious and downplayed the revelations of a covert Iranian nuclear programme, calling nonproliferation concerns a 'means of squeezing Russian companies out of the Iranian market' in 2003 (Parker, 2009, 221). Such a statement neatly captures the Russian zeitgeist at the time on the nexus between non-proliferation and legitimate nuclear cooperation that continued to underwrite Russian foreign policy in the Iranian nuclear dossier for the years to come: Russian economic benefits had to be weighed against political and security concerns of technology sales to Iran that might be of a dual-use nature. Russia's official position thus indicated non-compliance with the U.S. state of alert and apprehension regarding early signs of an emerging securitisation of the Iranian nuclear issue. It was already at this early juncture in the Iranian nuclear crisis that different security conceptions towards Iran's nuclear programme between the U.S. and Russia became apparent. If the rendition of enmity is an order-constituting and arguably hegemony-sustaining exercise (Agamben, 2002, 25), publicly challenging such a process of securitisation is resistance to hegemony on a discursive level.

Terms such as the 'pursuance of national interests' therefore have to be understood as relational concepts: What reads as an act of defiance for hegemonic powers can be an act of necessary resistance against instrumental politicisations in a non-hegemonic reading. Tellingly, the abrogation of the 1995 Gore-Chernomyrdin Commission under president Putin 
in 1999 (Antonenko, 2001) had effectively put an end to U.S.-Russian consultations concerning arms and technology transfers to Iran. Putin continued defending the Bushehr project and thereby indirectly sat on the fence when it came to judging the security implications of an Iranian nuclear programme in a Western reading. The United States was trying hard to end Russia's nuclear cooperation with Iran (Belopolsky, 2009, 101-107). In a Russian reading, Bushehr was a legitimate civilian nuclear power plant, unconnected to any hitherto covert uranium enrichment facilities, as re-iterated by a Russian foreign ministry official in an interview. ${ }^{4}$ Recurrence to 'legitimate' projects conveys a sense of selfdetermination and independence from other actors' alarmist rhetoric about nuclear Iran and calls to mind the relational dimension of security cultures: In the context of a looming securitisation of Iran's nuclear dossier in the first half of the 2000s, Russian recurrence to 'legitimacy' in international politics and external economic policies aimed to position Moscow against the outlining U.S. approach to Iran's nuclear programme. Russian official statements after the conclusion of the political framework agreement on 2 April 2015, negotiated in Lausanne between the P5+1 and Iran, served as a reminder that Russia had supported Iran's right to peaceful nuclear energy all along (Russian foreign ministry 2015).

From the beginning of the nuclear stand-off in 2002, Putin repeatedly emphasised the Iranian right to nuclear power (Putin, 2003; Mousavian, 2012, 163). This, as well as the track record of nuclear cooperation between Russia and Iran made Russia the logical candidate in Iran's search for allies as international public opinion turned against Iran and as Western governments grew more impatient with the Iranian lack of cooperation and transparency while talks over the nuclear programme proceeded. In a broader 'Eastern bloc approach' embraced especially with the coming into office of president Ahmadinejad in 2005, Iran reached out to Russia, China and the Non-Aligned Movement, hoping to find an international coalition supportive of Iran. Especially the support of China and Russia, two permanent UNSC members, was deemed crucial in resisting U.S. pressure (Mousavian, 2012, 84; 141). 
This was the case in the run-up to the first IAEA Board of Governors meetings in 2003 dealing with Iran, and in the course of the following years when referral of the Iranian nuclear file from the IAEA to the UNSC still might have been prevented. Ideologically inflated as a 'looking to the East' policy with the advent of Ahmadinejad as president and Ali Larijani as chief nuclear negotiator, Iran was trying to garner support of these states in order to build a broad anti-U.S. coalition to break the format of Iran facing Western negotiation partners over its nuclear programme that met increasingly fierce opposition (ibid., 190f.).

Therewith, however, Iran was misinterpreting Russian intentions: Following Iran's resumption of nuclear enrichment activities in August 2005 after a period of temporary suspension (Jafarzadeh, 2007, 159), testimony to the failure of nuclear negotiations between Iran and the EU3, the file was referred to the UNSC in March 2006. Of the 35 members of the IAEA Board of Governors, 27 endorsed the board resolution, of which Russia was one. The Russian endorsement became possible after a reference to 'international peace and security' has been omitted. An earlier resolution had still contained the reference and was therefore vetoed by Russia (Fitzpatrick, 2006, 21). The Iran nuclear case now had been transferred from Vienna to New York. Russia, hesitant to join the negotiations at first (International Crisis Group, 2006, 14), was forced to take a stance by now at the latest by nature of its permanent Security Council membership.

In U.N. Security Council negotiations, Russia found itself in a camp with China arguing for a less pressuring approach to Iran than the U.S. and European countries were pushing for and argued against the adoption of a UNSC resolution (Patrikarakos, 2012, 224; Mousavian, 2012, 235). In an attempt to broker a political solution to the crisis, Russia proposed a plan in 2006 by which Iran would have to transfer its enrichment programme onto Russian soil while still benefitting from its output. ${ }^{5}$ The idea of such a transfer was quickly rejected by the Iranians. This decision signaled to Moscow that Iran would not accept 
indefinite reliance on Russia in the field of nuclear technology and constituted a watershed both for Russia's perception of the Iranian goals and for U.S.-Russian cooperation over the Iranian nuclear file: Not only did this episode prove the "total failure of the "looking to the East" policy', it 'opened a new chapter in the nuclear standoff in which Russia began to move closer to the West,' as former spokesperson for the Iranian nuclear programme Houssein Mousavian (2012) writes in his memoirs (256-7). And after the failure of renewed E.U. and P5+1 incentives to reach a politically acceptable compromise in the following months, Russia did not make use of its veto right and approved of UNSC resolution 1696 in July 2006, which used the operative wording of a 'threat to international peace and security' that Iran constituted. Pursuing a more U.S.-independent foreign policy line while at the same time increasingly aware of the Iranian delaying techniques and against the background of the rejection of 'the Russian plan', Russia voted for UNSC Resolution 1737 in December 2006, approving for the first time the imposition of chapter VII sanctions on Iran.

While Russia aimed at averting or at least slowing down international pressure on Iran, it aimed at slowing down Iran's advances in its nuclear programme at the same time. This was evidenced by the constant pushing back of the date of completion of the Bushehr power plant, which, on the surface of it, was attributed to 'technical' issues (Katz, 2010, 64; 2012, 58), but was also read as a Russian sensitivity to US concerns (cf. also Nizameddin, 2013, 266), and equally prolonged the Iranian dependence on Russian technology. ${ }^{6}$ While this strategy can be read as a rational commercial calculation, it also served to show responsiveness to U.S. security perceptions and fulfilled a double purpose for Russia in this sense. Russia's public statements against unhelpful pressure on Iran entailed advocacy for a security culture that resisted U.S. hegemony, while Moscow still managed to steer a course that was avoiding outright rejection of U.S. policies. In analysing Russian Iran policy, it thus seems useful to make out a distinction between a discursive level (public advocacy for a security culture that is resisting hegemony), and a behavioral level (eventual approval for UNSC sanctions 
resolutions and a renouncement of unwavering support for the Iranian position), which will be elaborated upon more extensively in the following sections.

\section{Moscow's Approach to UNSC Sanctions and Reaction to U.S. and E.U. Unilateral Sanctions: Normative Divergence}

In accordance with the Russian hesitance when it comes to international sanctions against Iran, Moscow has always reiterated the importance of dialogue and diplomacy, rejecting a military solution to the crisis and calling on Iran to comply with the IAEA. In addition to braking the sanctions track, Moscow has thus (in tandem with China) worked toward weakening their impact by watering down provisions contained in the UNSC resolution drafts (Kuchins and Weitz, 2009, 176).

Moscow's eventual support for pressure and sanctions on Iran was a double-edged sword: Russia appeared to heed to U.S. concerns about the Iranian nuclear activities and, unofficially, made sure that it would remain the exclusive provider of nuclear fuel for Iran by slowing down Iran's nuclear advances. At the same time, it angered the Iranians and shattered any illusion that Russia was a reliable ally and would always protect Tehran from Western pressure. In Tehran, the impression was fuelled that the Iranian nuclear programme constituted a 'bargaining chip' for Moscow and that 'Russia is intentionally stalling in dealing with Iran to wring concessions from the United States' (Mousavian, 2012, 93). With Russia approving of successive rounds of UNSC-backed international sanctions, Iran had learnt that it could not rely on Russia as a diplomatic shield. But the disillusionment was mutual: Also in Russia, official voices began to worry that 'Tehran had [...] outsmarted Moscow by using Russia's diplomatic screen to advance Iranian goals that were inimical to Russia's own security interests' (in Parker, 2009, 249). Russian-Iranian nuclear cooperation thus by no means implied an automatic lenience with Iran in the nuclear talks. Russia's history of nuclear partnership with Iran was fraught with mutual frustration and occasional public accusations. 
Russia's support for U.N. sanctions under chapter VII thus has to be seen in this context of Russian skepticism regarding Iranian intentions and of wanting to be seen as a constructive partner for the Western interlocutors. The calculation was a mixture of geostrategic as well as global power political considerations, as will also be seen further below. Remarks delivered by Russia's UN representative, Vladimir Churkin, in Security Council sessions that passed the sanctions resolutions, conveyed a balance between the cautious admonition of Iran's failures to address international concerns about its nuclear file and a principled reservation regarding the use of restrictive sanctions (UN 2006, 2-3; UN 2007, 10-11; UN 2010, 8-9).

Russian approval for sanctions also was a reaction to political circumstances at the time that would have made resistance to sanctions difficult to sell politically. This was the case with the revelation of the existence of Iran's second uranium enrichment facility in Fordow near Qom in September 2009, hitherto unknown to the IAEA, ${ }^{7}$ and also to Russian intelligence services (Parsi, 2012, 126; Mousavian, 2012, 397). Russia was taken by surprise and therefore angered by the Iranian lack of transparency, but was also not pleased by the fact that Western intelligence sources had not been shared with Moscow (ibid.). Another undercurrent was the fact that Iran had rejected the Vienna group's proposal in 2009 that had centered around Russia as a key actor in the fuel swap deal. ${ }^{8}$ The latest sanctions regime against Iran was approved by the U.N. Security Council in June 2010 with Resolution 1929. Russia's vote for sanctions therefore also has to be seen in the context of this political momentum, where Russia's frustration with the Iranian lack of cooperation was one factor in the calculation and where a veto in the UNSC would have constituted an outright rejection of (not only Western) security political concerns regarding Iranian non-compliance with previous resolutions and IAEA safeguards agreements, as demonstrated again with the revelation of the Fordow facility.

In addition, Russia's approval of international sanctions often was linked to 
concessions offered by the U.S. administration in exchange for Moscow's consent in the sanctions question. The controversial Missile Defense (MD) episode in U.S.-Russian relations has become interlinked with Iran sanctions in the U.N. Security Council when the Obama administration offered concessions in the MD plans (renouncement of the missile defence shield deployment in Poland and the Czech Republic) and would be guaranteed Russia's cooperation in the Iran nuclear file, e.g. Russian green light for a new round of international sanctions on Iran (Mousavian, 2012, 335; Kuchins and Weitz, 2009, 168; Patrikarakos, 2012, 256). President Medvedev's public reaction to a secret letter by Obama about such an Iranmissile shield bargain indicated that Moscow was not happy to publicly discuss the matter (France24, 2009). The fact that Moscow did not reconsider its support for sanctions in June 2010 after the surprising Brazilian-Turkish diplomatic break-through in May 2010 and Tehran's unexpected approval of the Tehran declaration, however, goes to show that Russia had been promised too many important concessions by the U.S., as Trita Parsi contends (2012, 196). Russia even suspended the planned sale of its S-300 long-range air-defense system to Iran. Medvedev issued presidential decree 1154 in October 2010 to that effect. Esfandiary and Fitzpatrick (2011) even contend that Russia "went beyond the strict reading of the UN sanctions by cancelling (the S-300 contract) [...], a move that may have had the most significant impact on Iran of any national measure" (145) - a decision that has even been likened to Russia's own unilateral sanctions on Iran (Kozhanov 2015). ${ }^{9}$ The importance of the Iran issue and the acknowledged necessity to work with the Russians on Iran has been an important (if not the most important) motivation behind the US-Russian 'reset' policy in 2009, as confirmed by former State Secretary Clinton in her memoir (Clinton 2014, 235).

Russia was and is skeptical of the use of sanctions as a means of pressuring Iran into compliance. In contrast to Russia's grudging acceptance of international sanctions, however, unilateral sanctions as imposed by the U.S. and the E.U., it is being reiterated from the Russian foreign ministry, are not seen as legitimate instruments of international politics 
(Russian foreign ministry, 2012; Medvedev, 2010; Reuters, 2010; Sheridan, 2009). 'We view unilateral sanctions as illegal', a Russian foreign ministry official working on the Iranian nuclear dossier puts it in an interview. ${ }^{10}$ Next to the finding that unilateral sanctions have 'only brought a disrupture of the E3+3 dynamics' (ibid.), such a frank statement conveys Russian conceptions of legitimacy in international politics. Sanctions, imposed unilaterally by the U.S. and the E.U., are viewed as breaching a normative framework that should govern international relations. 'Rules and models' of the U.N. system, in Katzenstein's terminology $(1996,21)$ to understand 'culture', are not adhered to if sanctions are adopted outside of the U.N. Security Council.

While presented in Russian public diplomacy as motivated by the adverse effect sanctions have on diplomacy, Russia's rejection of unilateral sanctions and hesitancy to use international sanctions is also to be explained by the adverse effect these have on Russian companies: In the context of a growing anti-Iran climate in Western policy circles as the nuclear dossier was dragging, the U.S. criticised Russian exports of weapons and defensive systems and explicitly started sanctioning Russian firms for conducting controversial business with Iran. The aircraft manufacturer Sukhoi and arms exporter Rosoboronexport were sanctioned in 2006, 2007 and 2008 (Defense Industry Daily, 2006). ${ }^{11}$ The U.S. thereby was aiming at hampering what was perceived as a 'cynical' Russian two-track policy in which Moscow was officially committed to the international sanctions regime but not supporting the spirit of it. Russia, as demonstrated by its language on sanctions, is motivated by a normative understanding of their (il)legitimacy. But it is equally motivated by the material dimension of the effect of sanctions. This finding differentiates Russia's stance on the sanctions regime: While Moscow criticizes the political effects of sanctions, its compliance with the latter appears to be selective and dependent on the U.S. position, the impact of sanctions on Russia, and the nature of the sanctions adopted (unilateral or international).

The following section will put such an interplay between material and normative 
considerations for Russia's sanctions policy into the wider perspective of Russia's public diplomacy surrounding the Iran case and introduce the idea of Russian mediation as a final element that adds to Russia's security culture on Iran. The article therewith weaves together the discursive and the behavioral dimensions of a two-level model to understand Russian Iran policy. This will answer the question how Russia's foreign policy towards Iran's nuclear programme is illustrative of a security culture that resists hegemony.

\section{Russia in the Iranian Nuclear Dossier: Constructive Mediation and Behavioral Convergence}

As has been analysed in the previous sections, Russia always had to reconcile security perceptions with legitimate commercial aspects of Russo-Iranian relations. As much as this had been a source for disagreement between Russia and its Western counterparts, it had demonstrated Russia's defense of a security culture that would resist securitising discourses, which were presenting Iran's nuclear programme as an inherent threat and basing policies on allegations. In the second half of the 2000s, however, decisions by the Iranian leadership had alienated Moscow and contributed their part in bringing Moscow to agree to the imposition of sanctions. And when in May 2010, Russia approved of sanctions resolution 1929 in the U.N. Security Council, it had agreed to the toughest round of sanctions ever imposed on Iran over its controversial nuclear programme so far - a seeming reversal of Moscow's position from only five years before.

The depiction of Russia's role in the Iran dossier as being that of a veto-player indulgent with the Iranians would therefore be a fallacy. In its official diplomacy, Russia was always emphasizing the need to find a political solution to the nuclear crisis through dialogue. Proposals such as the creation of an international fuel center on Russian soil by president Putin are a case in point (Diakov, 2007, 135f.; ElBaradei, 2011, 137). Russian officials stress 
that Moscow has introduced several constructive proposals in the search for solutions to the Iran nuclear crisis, some of which are known (like Lavrov's 'step-by-step' plan in 2011 or the proposal for an international fuel consortium in 2006), while others are unknown to the public and were circulated within the P5+1 format. ${ }^{12}$

Reiterating the importance of constructive dialogue and Moscow's contribution to that end, Russian foreign ministry officials noted the similarity between the proposal discussed in Geneva in November 2013 and Lavrov's earlier step-by-step proposal. ${ }^{13}$ In line with Russia's desire to be perceived as a responsible global power, such interpretations reflect on Moscow's willingness to be seen as a cooperative and pragmatic dialogue partner in the Iranian nuclear file. Seyed Hossein Mousavian (2012) even writes that it was a strategic mistake of the West not to have given the Russian 'step-by-step' plan more consideration (457).

Especially during the Medvedev administration, Russia managed to highlight issue areas for closer cooperation with the West and nurtured the impression of Moscow as a constructive dialogue partner in the Iran dossier, but also in the U.S.-Russian dialogue in security affairs in general. In the case of the controversy over the Iranian nuclear programme, the non-delivery of the S-300 defense system to Iran, which would allow the interception of long-range missiles to an even greater extent than the S-200 system does, was such an example of a slightly more accommodating foreign policy toward Western security political concerns. The cancellation of the S-300 delivery was a major annoyance for Iran with which Russia squandered a good deal of its 'leverage power' over Tehran. But as was also shown above, this should not necessarily be attributed to an ideational convergence of Western and Russian security cultures. It arguably was the concrete outcome of a tangible 'quid pro quo' policy between the US and Russia. The importance of the Iran issue and the acknowledged necessity to work with the Russians on Iran has arguably been an important motivation behind the U.S.-Russian 'reset' policy in 2009 (cf. also Parsi 2012, 94; Fitzpatrick 2010, 71; Kozhanov 2015). ${ }^{14}$ 
In spite of Moscow's foreign policy discourse suggesting otherwise, Russia oftentimes worked constructively with its Western counterparts on a behavioral level. This observation has even remained true in the wake of the 'Ukraine crisis' as a catalyst for an unprecedented deterioration in relations between Russia and the West. While this crisis has seen the suspension of working-level contacts on most other policy domains, a constructive level of collaboration between Russia and the West on Iran has remained intact - despite occasional public flirtations with the idea of using the Iran nuclear talks as a vehicle for obstructionism to force the West to reconsider its sanctions policy against Russia. ${ }^{15}$ Despite public warnings and a gloomy rhetoric on a discursive level, however, retaliatory moves affecting the Iranian nuclear talks did not materialise on a behavioral level yet. This finding is indicative of the high importance that Moscow has attached to a political solution to the simmering Iranian nuclear conflict (cf. also Meier \& Pieper 2015). The following section suggests a number of reasons why that is so, and thereby weaves together the research findings of the previous sections with the two-level distinction between a discursive and a behavioral dimension of foreign policy that was worked out before.

\section{Russia between Constructive Mediation and Status Quo Politics: Resistance to Hegemony?}

A peculiar combination of factors lets Russia resist U.S. policies, while on other occasions, U.S. pressure on Iran and the upholding of tensions surrounding Iran's nuclear programme is supported by Russia. This section disentangles this seeming variation in Russia's foreign policy line by following the two-level model of a discursive and a behavioral dimension of Russia's Iran policy as introduced earlier. A number of material factors will therefore be analysed to complement the preceding analysis of Russia's discourse and role perception. Linking these two levels to the concepts of normative divergence and rules convergence as analysed above allows me to conclude on the nexus between Russia's security culture on Iran 
and resistance to hegemony.

A first factor in Russia's support for pressure on Iran on a behavioral level is Russia's comparative advantage on the European gas and oil market. Skeptics have pointed out that this is the strongest counterargument for Moscow to be genuinely interested in a long-term solution to Iran's nuclear crisis. Should Iran's final nuclear status be settled, a partial normalisation of relations between Iran and the West would ensue. As a result, Russia could, in the mid- to long term, be faced with the emergence of a competitor on the European energy market. Russia's current near-monopoly position on the European gas and oil market, so the reading, would be endangered. The scenario of a sudden Iranian oil and gas competitor, however, does fall short of accounting for more nuanced market structures: Even before the imposition of the EU's oil embargo against Iran in 2012, Iran provided a stable $6 \%$ of the EU's oil imports (Eurostat 2012). Russia's share is around $30 \%$. Russian officials are thus relaxed about the prospect of Iran becoming a rival on the European oil market any time soon - even after the lifting of Iran sanctions. ${ }^{16}$ A similar expectation prevails for the gas export market: Russia's share on the European gas market lies at $30 \%$. Even though Iran holds the world's second largest gas shares, it lacks the production and transportation structures. Russia also knows that the existing pipeline structure benefits Russian gas interests, while pipelines from Iran to Europe do not exist and would have to be built. ${ }^{17}$ Even alternative projects like the Trans-Anatolian Pipeline (TANAP) and the Trans-Adriatic Pipeline (TAP) would transport natural gas from Azerbaijan and thus circumvent Iran. Yet, the rapid deterioration in relations between Russia and the EU in the course of the Ukraine crisis has sped up Europe's efforts to diversify its energy sources away from Russia (European Commission 2015). While the prospect of Iran becoming an important energy supplier for Europe is still unclear, it cannot be excluded that political dynamics have the potential to shake Russia's position on the European energy market. 
A second factor explains why pressure on Iran is advantageous for Russia as long as this pressure upholds tensions without leading to escalation: Russia has commercial interests in Iran that could see tougher competition once tensions with Iran are eased in the wake of a comprehensive nuclear agreement. Russian economic activities in Iran are low. The historically more significant weapons trade has shrunk as a consequence of UN weapons embargoes. Yet, cooperation in the nuclear technology area (Bushehr) has been the flagship of Russian-Iranian economic cooperation, despite mutual accusations and frustrations as described above. On 11 November 2014, Rosatom announced its intention of construction eight additional nuclear reactors in Iran. The Russian government knows that a military escalation of the Iran conflict would have destructive consequences on a Russian built-up of stronger economic relations including the deepening of nuclear technology cooperation, whereas the upholding of certain tensions could be rather beneficial in this regard. Western tensions with Iran guarantee Russia a certain market position that results from the absence of Western competition. A normalization of Iran's relations with the West could change this equation. This is especially true if a nuclear agreement between Iran and the P5+1 were to pave the way for the lifting of sanctions that could bolster a renewed international investment in and trade with Iran. Russia, in this scenario, could stand to lose from a nuclear agreement from a purely commercial point of view. It is not always clear, however, whether the furtherance of nuclear technology cooperation is a purely commercially-driven project (by Rosatom), or whether Rosatom's Iran projects are not at least partially co-decided by Russia's political leadership (cf. also Belopolsky, 2009, 58).

Another scenario is that of a resolution of the nuclear issue without a broader political normalization of Iran's relations with the West, which could create an 'empty space' in Iran, possibly to be filled by Russian investments. ${ }^{18}$ However, it has been pointed out that the Russian-Iranian trade volume does not account for a big share on either side's external trade balance: Russia's trade with Israel almost reaches numbers comparable with Russian-Iranian 
trade, despite the fact that Israel's population is ten times smaller than Iran's (Sazhin 2010). The Iranian-Turkish trade volume is seven times higher than the Russian-Iranian; Iran's trade volume with China is even 13 times higher than the one with Russia.

Third, and arguably the most important reason from a global power and prestige perspective, Russia's self-understanding of being an unavoidable global power player enters into the calculation about the direction Russia's Iran policy ought to take. Russia, as a permanent UNSC member, wants to be understood as a state among equals. In line with Sakwa's concept of 'neo-revisionism', it is understood here that Russia's working with international organizations of the U.N. system does not constitute an appeal by Moscow to fundamentally challenge the system of international governance, but to partially revise its functioning (Sakwa, 2011; 2015, 28-31). This observation ties in with the distinction made earlier between 'rules and models' versus 'norms and values' (Katzenstein, 1996, 21). While Russia supports and adheres to the 'rules' and basic functioning of the U.N. system, its disagreement with other U.N. members and U.S. power structures reveals a different normative understanding of what is deemed legitimate in international relations. The concept of 'neo-revisionism' thus captures the strife towards more equitable and non-hegemonic international relations, while falling short of outright opposition to hegemony. In his speech at the Valdai club in 2014, president Putin thus explained the root cause of the current frosty relations between the West and Russia as follows: 'The Cold War ended, but it did not end with the signing of a peace treaty with clear and transparent agreements on respecting existing rules or creating new rules and standards' (emphasis added). While 'norms' can differ, so the message, a rules-based arrangement between Russia and the West should have ensured an equitable co-existence. ${ }^{19}$

In practice, this implicitly should entail a Western awareness and acknowledgment of Russia's status as a Great Power, in a Russian understanding. Russia is thus very aware of its 
power to veto new sanctions rounds in the UNSC. Russian skepticism voiced during the nuclear talks in Lausanne in March and April 2015 over a 'snap back' provision that would automatically re-impose sanctions on Iran if the latter was found in non-compliance with its agreements was indicative in this regard (Gordon \& Sanger 2015): Moscow's concerns hinted at the dilution of its veto power that a Security Council authority over sanctions matters entails. Combined with deliberations about the state of U.S.-Russian relations, Russia's Iran and Middle East policy can tip the scales in a process either towards greater consultation with the Russians or towards international isolation of Russia (Katz 2008). Russia's foreign policy towards the Syrian civil war is a case in point for the implications of Russian resistance to U.S.-inspired power structures. In its support for the Assad regime, Russian and Iranian regional interests are converging, while the West and Russia have been further drifting apart (Trenin, 2012). 'For Iran, it is an issue of regional balance of power and its own security, and for Russia it is an issue of upholding certain principles of international order and rejection of U.S. pressure', Lukyanov (2014) reflects on this geopolitical convergence of interests between Russia and Iran over Syria.

In a Western reading, Russia's foreign policy is thus perceived at times as rebellious, obstinate, and disruptive at worst. The most fundamental trust crisis in relations between the West and Russia that was unleashed over Ukraine has contributed its share in aggravating this perception. 'There is an abyssal mistrust in the West toward Russia', a high-ranking Swiss diplomat puts it in an interview. ${ }^{20}$ Understood against the backdrop of Russia's Great Power status understanding, however, such a political holding game should not be misconstrued as a revisionist agenda by a renegade Russia. As Trenin (2013) argues with the example of Russia's Syria policy, Putin's attempt to disperse war speculations over Syria by introducing the idea of a destruction of Assad's chemical weapons arsenal in August 2013 was meant to restore equality in U.S.-Russian relations and reassert the understanding that Russia's voice cannot be overlooked in world politics. Moscow, so the Russian rationale, made international 
relations more 'democratic' again (see also Allison, 2013; Adomeit, 2013). The official Russian Foreign Policy Concept breathes this ambition to 'democratise' international relations (Russian foreign ministry, 2013). 'Democratisation' of international relations would thus accurately characterize Russia's understanding of a desirable security culture to govern international politics. In the reading that 'democratisation' entails the deconstruction of power hierarchies, this is an endeavor explicitly questioning hegemony. If international relations are 'democratic', existing power asymmetries are smoothed out, eliminating hegemonic structures by definition.

From the reasons outlined above, Russia's foreign policy discourse is cautious not to join the chorus of voices advocating a punitive stance on Iran over its controversial nuclear programme. Moscow's foreign policy discourse displays a normative divergence with hegemonic policies and advocates for a non-hegemonic security culture on Iran. At the same time, Russia was admonishing the Iranian leadership to work transparently with the IAEA and comply with UNSC resolutions. Russian public diplomacy thus serves a double purpose: To make clear to its Western counterparts that one-sided pressure or, worse even, interference in Iran's domestic structures, will not be supported by Russia and is not consistent with Russia's security culture, while still conveying the impression that Russia is interested in constructive mediation, as analysed above. Such a position demonstrates Russia's pragmatism in seeking to avoid infuriating one side or the other, while a certain level of tensions surrounding the Iran case can even be beneficial for Russia, as outlined in this section. Russia is, in the words of Patrikarakos (2012), 'quite comfortable with the status quo of neither a deal nor a crisis' (251). When push comes to shove, however, Russia has always engaged in diplomatic mediation to avert the scenario of a military confrontation with Iran and the resulting instability in the region. A new war in the Middle East, so the Russian rationale, is a bigger evil than Iran potentially acquiring nuclear weapons. ${ }^{21}$

Throughout the decade-old complexities of international politics surrounding the 
Iranian nuclear case, Russia has alternated in alienating both 'the West' and Iran: Russia is not shying away from resuscitating potentially controversial deals at a later moment in time that had been temporarily halted due to U.S. pressure and (unfavorable) international attention. The much-discussed S-300 deal is a case in point: Frozen under U.S. pressure in 2009 by the Medvedev administration and suspended after the adoption of UNSCR 1929 in 2010, Putin cancelled the suspension just two weeks after the political framework agreement with Iran had been signed in Lausanne. Likewise, Russian support for UNSCR 1929 in 2010 in exchange for U.S. concessions was another example of a rather pragmatic behavior that analysts have described as 'horse-trading'22 - which was sure to have angered the Iranians. The impression prevails that while Russia is purporting to propose plans in the P5+1/E $3+3$ format (the Russian plan, the Lavrov plan), a plethora of Russian commercial interests, Russian energy politics and its global agenda enter the equation as aspects that might make the Kremlin lean towards a status quo-holding game. Russian deputy foreign minister Sergei Ryabkov's public statement on 20 March 2014 that Russia could reconsider its stance on the Iranian nuclear issue in the face of increasing Western pressure over Moscow's confrontational line in the Ukraine crisis was another indication for the impression that Russia occasionally has used the Iran nuclear talks as a 'bargaining chip' to get concessions in other issue areas (Fitzpatrick, 2014).

A high-ranking Swiss diplomat therefore bluntly formulates: 'Nobody trusts the Russians'. ${ }^{23}$ Russia's foreign policy in the Iranian nuclear dossier is torn between the public advocacy for more 'democratic' international relations and a security culture that understands security as security from hegemonic frameworks on the one hand and a behavioral level of political dependence on the US that makes Russia follow a partially accommodating course on the other. Dmitri Trenin (2014) speaks of a 'compartmentalized environment' defining U.S.-Russian relations and a pragmatic approach to specific issue areas in which both cooperation and disagreement is possible at the same time. Russia's approach to multilateral 
cooperation, in other words, remains ad-hoc. The understanding of 'trade-offs', in a positive reading, also allows selective cooperation on some issues areas, even when conflicting interests prevail in others, as the Iran-Ukraine issue has illustrated.

Conveying a normative divergence with the ideational framework of hegemony, Russia's balance on a behavioral level is thus more mixed. Moscow displays compliance with international sanctions, while various material factors let Russia oppose a long-term solution to Iran's nuclear crisis, and other material factors advocate the latter. The behavioral level, in other words, does not coincide with the discursive level on which Russia advocates for a security culture resisting hegemony. Its foreign policy on Iran therefore is the outcome of a balancing act between hegemonic accommodation and resistance. ${ }^{24}$

\section{Conclusion}

This article has analysed the extent to which Russia's foreign policy towards Iran's nuclear programme is indicative of a security culture that resists hegemony. It thereby introduced a two-level distinction between a discursive and a behavioral dimension of foreign policy to examine the degree of resistance to hegemony. It has been shown how Russia conveys resistance to hegemony on a discursive level by emphasizing the legitimate nuclear rights of Iran, the legitimacy of Russian commercial ties with Iran, the counterproductive effect of sanctions and the illegality of Western unilateral sanctions. On a behavioral level, Russia was slowing down the sanctions track when the Iranian nuclear file was referred to the UNSC in 2006, but eventually adopted and complied with international sanctions, yet was blacklisted for trade with Iran that ostensibly contravened the sanctions regime. At the same time, an occasional remarkable degree of pragmatic cooperation with the U.S. on the Iran file has been observed - not only at the peak of the Obama-Medvedev 'reset' policy, but also in diplomatic negotiations in the $\mathrm{P} 5+1$ format.

Russian foreign policy toward Iran and its nuclear programme thus has always to be 
seen in the overall context of Russia's political relations with 'the West' generally, and with the U.S. in particular. Russian foreign policy following the break-up of the Soviet Union underwent distinct phases of foreign policy re-orientation toward the West, ranging from assimilationist to more assertive and independent foreign policies that bespeak Russia's quest for a post-imperial foreign policy identity. ${ }^{25}$ These phases of re-orientation naturally had a fluctuating bearing on the act of balancing relations to the U.S. with relations to Iran: Commercial pragmatism and the fight for economic survival of Russian industries post-1991 had to be balanced against U.S. perceptions of Russian foreign policies and the desire to be perceived as a Great Power on equal terms after the dissolution of the Soviet Union. Russian foreign policy makes a distinction between purely commercial and legitimate nuclear technology usage (e.g. Bushehr), and a security political dimension of the Iranian nuclear programme ('Western allegations of military intentions remain unproven'). This was especially true since the revelation in 2002 of the hitherto covert nuclear programme of Iran. Moscow's strife to preserve Great Power status, coupled with justified security concerns about Iranian nuclear intentions explains its voting for sanctions resolutions against Iran sponsored by the U.S. - even though Russia publicly advocates a security cultures that breathes the ambition to 'democratise' international relations and resist U.S. pressure.

Russia shows a reluctance to agree to international sanctions on Iran, yet conveys a desire to be perceived as a constructive player in the Iranian nuclear dossier. A number of Russian initiatives (Putin's 2006 proposal for the multilateralization of the nuclear fuel cycle, the 2011 'step-by-step' plan, the creation of a fuel consortium on Russian soil etc.) are indicative of this Russian willingness to make a constructive contribution. It is also true that it cannot be in Russia's interest to see a nuclear Iran emerge on its Southern flank that would have obvious implications for the regional power balance and challenge Russia's nuclear monopoly in the region. But while a nuclear Iran cannot be in Russia's interest, Moscow does not support any regime change plans. Russia emphasizes the need to find a diplomatic 
solution to Iran's nuclear crisis, but the upholding of tensions (and temporary non-resolution of the crisis) may even be beneficial for Russia for the reasons outlined in the last section of this article. Russian foreign policy here essentially amounts to a hedging strategy that avoids alienating one side or the other too much by upholding the rhetoric propagating diplomatic engagement and political solutions, while implicitly contributing to the upholding of a certain political status quo situation.

Russia and its Western counterparts in the P5+1 framework occasionally appear to be standing on two opposite ends of the spectrum of political instruments when it comes to approaching Iran. As this article has shown, however, taking such disagreements as signs of an unalterable freezing into mutually opposed camps and portraying Russia as a cumbersome veto player in the UNSC, blocking and derailing Western negotiation efforts, does not do justice to much more complex foreign policy positions that have to bridge official discourse(s) with largely material, global power political and security motivations. This two-level foreign policy between a discursive level advocating non-hegemonic governance models, and a behavioral level on which Russia takes policy decisions that run counter to that ideal underlines the complexities of Russia's Iran policy that cannot solely be captured by a policy of 'resistance to hegemony'.

Russia's Iran policy is an illustration of a state's foreign policy that challenges hegemonic structures, but works within the system of governance inspired by the U.S. It is an example of a friction between contestation and accommodation, between resistance and consent. Russia's search for a foreign policy identity, like that of any other state, is an iterative process as the outcome of the state's international context, its self-understanding, and the perception thereof by other actors. 'Security' is always contextual, ideas and identities always co-constructed by the social environment, and policy decision never taken in a vacuum. This finding explains the seeming variation in Russia's Iran policy, where the 
advocacy for a security culture that resists hegemony does not always coincide with divergence from hegemonic structures on a behavioral level.

\section{Notes}

${ }^{1}$ Author's interviews with several officials close to the nuclear talks, March 2013-March 2015.

${ }^{2}$ Seyed Hossein Mousavian (2012) even asserts that Russia and Iran had been negotiating 'secretly for cooperation on an enrichment facility in Natanz and heavy-water reactors in Arak, but Russia halted this cooperation under pressure from the United States in the late 1990s' (55).

${ }^{3}$ most notably Germany and France

${ }^{4}$ Author's interview, Moscow, 18 April 2013.

${ }^{5}$ Referred to as 'the Russian plan'.

${ }^{6}$ With Bushehr, Moscow held leverage over Iran as far as fuel and the technical operation of the plant was concerned. Fuel fabrication and insertion is a technically difficult process and is best carried out by the actual producer of the plant. In addition, Iran needed the Russian technicians to operate the plant, as was also evidenced by the informal prolongation of the initially contracted two-year period during which Russian technicians were supposed to work in Bushehr. In this sense, through its nuclear technology cooperation, Moscow had channels through which it was able to make its voice heard in Tehran (Author's interview with Dr. Anton Khlopkov, Director of CENESS, Moscow, 17 April 2013).

${ }^{7}$ therewith also supposedly breaching IAEA modified code 3.1, which stipulates the acknowledgment of new facilities already as from their planning phase (IAEA, 2011).

${ }^{8}$ As confirmed by a former Russian diplomat to the embassy in Tehran. Conversation with author, Washington, 1 November 2014.

${ }^{9}$ On 13 April, two weeks after the conclusion of the political framework agreement with Iran in Lausanne, President Putin officially cancelled the suspension and paved the way for an eventual delivery (BBC 2015).

${ }^{10}$ Author's interview with Russian foreign ministry official, Moscow, 18 April 2013.

${ }^{11}$ Along with Rosoboronexport, the Bush administration also sanctioned the Tula Instrument-Making Design Bureau and the Kolomna Machine-Building Design Bureau in 2007. The sanctions against Sukhoi, imposed because of alleged violations of the Iran Nonproliferation Act of 2000 were lifted again in November 20006.

${ }^{12}$ Author's interview with Russian foreign ministry official, Moscow, 18 April 2013. 
${ }^{13}$ Author's interview with Russian foreign ministry official, Moscow, 12 November 2013.

${ }^{14}$ Dr. Alexei Arbatov, head of the Center for International Security at IMEMO, asserts that the S-300 decision was the 'peak' of the US-Russian reset policy. Author's interview, Moscow, 13 November 2013.

${ }^{15}$ This impression was first nurtured when on 19 March 2014, Russian deputy foreign minister Sergei Ryabkov stated that Russia could reconsider its position on the Iranian nuclear dossier in the context of Western sanctions discussions directed against Russia.

${ }^{16}$ Author's interview with Russian diplomat, Brussels, 19 March 2015. Email correspondence with Russia diplomat, 12 March 2015; Author's interview with Russian diplomat, Brussels, 7 October 2014.

${ }^{17}$ Author's interview with Russian diplomat, Brussels, 19 March 2015.

${ }^{18}$ This point was made by Dr. Vladimir Sazhin, author's interview, Moscow, 17 April 2013.

${ }^{19}$ Western responses to this reading usually hold that the Russian reference to mutual respect and equality in diplomacy often is upheld as a disguise to breach international obligations.

${ }^{20}$ Author's interview in Berlin, 26 August 2013. Similar points were also made by Dr. Walter Posch, SWP, Author's interview, Berlin, 25 June 2013.

${ }^{21}$ Author's interview with Dr. Alexei Arbatov, Moscow, 13 November 2013.

${ }^{22}$ Author's interview with Dr. Ali Vaez, chief Iran analyst, International Crisis Group, via Skype, 25 July 2013.

${ }^{23}$ Author's interview, Berlin, 26 August 2013.

${ }^{24}$ Following Hassan Rouhani's election in June 2013, it can be argued that the U.S. position itself on a long-term solution to Iran's nuclear status has shifted. Russian opposition to such a final nuclear status, therefore, may be deviating from U.S. foreign policy. For analytical purposes, however, the reference point is Russia's compliance with its own discourse (behavioral inconsistency with a discursive level), instead of U.S. positions seemingly undergoing changes. Concerning the latter, it is argued that hegemonic structures still remain in place insofar as changing negotiation positions do not yet account for an overhaul of hegemonic structures. The sanctions regime is a forceful case in point.

${ }^{25}$ Casier (2006); MacFarlane (2006: 44f.); Sakwa (2002); Trenin (2006); Tsygankov (2007)

\section{References}

Adomeit, H. (2013) Fehler im Betriebssystem. Die russisch-amerikanischen Beziehungen. Osteuropa 63(9): 57-78. 
Agamben, G. (2002) Homo sacer. Die Souveränität der Macht und das nackte Leben. Trans. Hubert Thüring. Frankfurt: Suhrkamp.

Allison, R. (2013) Russia and Syria: explaining alignment with a regime in crisis. International Affairs 89(4): 795-823.

Antonenko, O. (2001) Russia's Military Involvement in the Middle East. Middle East Review of International Affairs 5(1).

BBC (2015) Russia lifts ban on S-300 missile system delivery to Iran. BBC World News, 13 April 2015, http://www.bbc.co.uk/news/world-europe-32290335, accessed 22 April 2015.

Belopolsky, H. (2009) Russia and the Challengers. Russian Alignment with China, Iran, and Iraq in the Unipolar Era. Basingstoke: Palgrave Macmillan.

Casier, T. (2006) Putin's Policy Towards the West: Reflections on the Nature of Russian Foreign Policy. International Politics 43: 384-401.

Clinton, H. R. (2014) Hard Choices. New York: Simon \& Schuster.

Cox, R. (1996) Approaches to World Order. Cambridge: Cambridge University Press.

Defense Industry Daily (2006) US Ban on Russian Defense Firms Raises the Stakes. 11 August 2006, http://www.defenseindustrydaily.com/us-ban-on-russian-defensefirms-raises-the-stakes-02522/, accessed 17 October 2013.

Diakov, A. (2007) The Nuclear Fuel Cycle. In: A. Arbatov (ed.) At the Nuclear Threshold. The Lessons of North Korea and Iran for the nuclear non-proliferation regime. Moscow: Carnegie Endowment for International Peace.

ElBaradei, M. (2012) The Age of Deception. Nuclear Diplomacy in Treacherous Times. New York: Bloomsburg Publishing Plc.

European Commission. 2015. Energy Union Package. Communication from the European Commission to the European Parliament, the Council, the European Economic and Social Committee, the Committee of the Regions and the European Investment Bank: A Framework Strategy for a Resilient Energy Union with a Forward-Looking Climate Change Policy. European Commission Communication COM(2015) 80, 25 February 2015, http://ec.europa.eu/priorities/energy-union/docs/energyunion_en.pdf, accessed 13 April 2015.

EU Council Conclusions (2012) Iran: E.U. strengthens sanctions over lack of progress in nuclear talks. EU Council Conclusions, http://www.consilium.europa.eu/uedocs/cms_Data/docs/pressdata/EN/foraff/132849. pdf, accessed 15 February 2013.

Eurostat (2012) EU Oil Imports, by country of origin. Statistics Explained, 19 July 2012, http://epp.eurostat.ec.europa.eu/statistics_explained/index.php?title=File:EU_Oil_im ports,_by_country_of_origin_(in_\%25).png\&filetimestamp=20120719133014, accessed 16 October 2013.

Fitzpatrick, M. (2006) Iran and North Korea: The Proliferation Nexus. Survival 48(1): 61-80. (2010) Iran: The Fragile Promises of the Fuel-Swap Plan. Survival 52(3): 67-94.

(2014) The Ukraine Crisis and Nuclear Order. Survival 56(4): 81-90.

France24 (2009) Moscow rebuffs Obama's secret Iran-missile shield deal. 4 March 2009, http://www.france24.com/en/20090303-moscow-rebuffs-secret-obama-dealmedvedev-missile-shield-iran, accessed 19 October 2013. 
Gordon, M. R. and Sanger, D. (2015) Iran Agrees to Detailed Nuclear Outline, First Step Toward a Wider Deal. The New York Times, 2 April 2015, http://www.nytimes.com/2015/04/03/world/middleeast/iran-nucleartalks.html?hp\&action=click\&pgtype=Homepage \&module=first-columnregion\&region=top-news\&WT.nav=top-news\&_r=1, accessed 3 April 2015.

IAEA (2011) Implementation of the NPT Safeguards Agreement and relevant provisions of Security Council resolutions in the Islamic Republic of Iran. IAEA board report, 24 May 2011, http://www.iaea.org/Publications/Documents/Board/2011/gov201129.pdf, accessed 24 February 2014.

International Crisis Group (2006) Iran: Is there a way out of the nuclear impasse? Middle East Report Nr. 51, 23 February.

Jafarzadeh, A. (2007) The Iran Threat. President Ahmadinejad and the coming nuclear crisis New York: Palgrave Macmillan.

Katz, M. (2010) Russia-Iranian Relations in the Obama Era. Middle East Policy 17(2): 62-69. (2012) Russia and Iran. Middle East Policy 19(3): 54-64.

Katzenstein, P. J. (ed.). 1996. The Culture of National Security. Norms and Identity in World Politics. New York: Columbia University Press.

Kozhanov, N. (2015) Understanding the Revitalization of Russian-Iranian Relations. Carnegie Paper, 5 May 2015.

Kuchins, A. and Weitz, R. (2009) Russia's Place in an Unsettled Order: Calculations in the Kremlin. In: Schiffer, M. and Shorr, D. (eds.) Powers and Principles. International Leadership in a Shrinking World. Plymouth: Lexington Books.

Lata, V. and Khlopkov, A. 2003. Iran's Missile and Nuclear Challenge: A Conundrum for Russia. PIR Center report, 05 August 2003, http://www.pircenter.org/report/lata_0508-2003.pdf, accessed 20 March 2011.

Lukyanov, F. (2014) Russia plays the Iran card. Al-monitor, 17 January 2014, http://www.almonitor.com/pulse/originals/2014/01/geneva-ii-russia-syriadiplomacy.html?utm_source=dlvr.it\&utm_medium $=$ twitter\&goback=\%2Egde_1491 617_member_5830606003795693568\#\%21, accessed 20 January 2014.

MacFarlane, S.N. (2006) The 'R' in BRICs: is Russia an emerging power? International Affairs 82(1): 41-57.

Medvedev, D. (2010) In: Russia's Medvedev criticizes Iran sanctions: report. Reuters, 17 June 2010, http://www.reuters.com/article/2010/06/18/us-nuclear-iran-medvedevidUSTRE65H0M720100618http://www.reuters.com/article/2010/06/18/us-nucleariran-medvedev-idUSTRE65H0M720100618, accessed 19 October 2013.

Meier, O. and Pieper, M. (2015) Russland und der Atomkonflikt mit Iran. Kontinuitäten und Brüchen bei den russischen Interessen im Zeichen der Ukrainekrise. SWP-Aktuell 38: 1-4.

Mousavian, S. H. (2012) The Iranian Nuclear Crisis. A memoir. Washington: Carnegie Endowment for International Peace.

Nizameddin, T. (2013) Putin's New Order in the Middle East. London: Hurst.

Orlov, V. and Vinnikov, A. (2005) The Great Guessing Game: Russia and the Iranian Nuclear Issue, The Washington Quarterly vol. 28, no. 2.

Parker, J. W. (2009) Persian Dreams. Moscow and Tehran Since the Fall of the Shah. Washington, D.C.: Potomac Books, Inc. 
Parsi, T. (2012) A Single Roll of the Dice: Obama's Diplomacy with Iran. Yale: Yale University Press.

Patrikarakos, D. (2012) Nuclear Iran. The Birth of an Atomic State. London, New York: I.B. Tauris.

Pieper, M. (2014) Chinese, Russian, and Turkish Policies in the Iranian Nuclear Dossier: Between Resistance to Hegemony and Hegemonic Accommodation. Asian Journal of Peacebuilding 2(1): 17-36.

Putin, V. (2003) Intervyu Prezidenta Rossii V.V. Putina Amerikanskim telekanalam. NovoOgoreva. September 20, 2003 Soobsheniya Press Slujbi Prezidenta Rossiyskoy Federatsii. MID RF DIP, Informatsionniy Byulleten. Interview of American TV channels with Russian president V. Putin. Bulletin of the Press Service of the Russian Federation, 24 September 2003.

Trenin, D. (2006) Russia Leaves the West. Foreign Affairs July-August 2006: 1-6.

(2012) Russia and the West need to rediscover each other in 2013. Carnegie article, 24 December 2012, http://carnegieeurope.eu/publications/?fa=50468, accessed 21 January 2014.

(2013) Putin's Syrian Game Plan. World Today 69(8/9) 7 October 2013, http://www.chathamhouse.org/publications/twt/archive/view/194529, accessed 18 October 2013.

(2014) Russia: Sealing the New Quality of Its Foreign Policy. Eurasia Outlook, 20 January 2014, http://carnegie.ru/eurasiaoutlook/?fa=54244, accessed 22 February 2014.

Tsygankov, A. P. (2007) Finding a civilizational idea: 'West', 'Eurasia', and 'Euro-East' in Russia's foreign policy. Geopolitics 12(3): 375-399.

Reuters (2010) Russia warns U.S. against unilateral Iran sanctions. 13 May 2010, http://www.reuters.com/article/2010/05/13/us-russia-iran-usidUSTRE64C1SU20100513, accessed 19 October 2013.

Russian foreign ministry (2012) Kommentarii Departamenta Informatsii I Petshati MID Rossi na vopross agenst'va 'Interfax' otnositel'no vosmoshnosti provedenia 'Shesterkoy' novoy vstretshi s utshastiem Irana. Statement by the Russian foreign ministry press department on the question of 'Interfax' agency on the possibility of the new P5+1 meeting with Iran. Press statement, 17 October 2012, http://www.mid.ru/bdomp/nsrasia.nsf/1083b7937ae580ae432569e7004199c2/c32577ca0017458644257a9a00618e f9! OpenDocument, accessed 2 February 2014.

(2013) Concept of the Foreign Policy of the Russian Federation, http://www.mid.ru/bdomp/nsosndoc.nsf/1e5f0de28fe77fdcc32575d900298676/869c9d2b87ad8014c32575d9002b 1c38! OpenDocument, accessed 15 January 2014.

(2015) Sayavlenie MID Rossii po itogam peregovorov v Losannie ministrov inostranikh del "Gruppy Shesti" i Irana po voprocu ob ureglirovanii situatsii vokrug iranskoj yadernoj programmy. Foreign ministry statement on the foreign ministerlevel talks in Lausanne between the "Group of Six" and Iran concerning the resolution of the situation surrounding the Iranian nuclear programme. Statement, 2 April 2015, http://mid.ru/brp_4.nsf/newsline/1172F6446B05FF5C43257E1B0068E88B, accessed 4 May 2014.

Sakwa, R. (2002) Russian Politics and Society. London and New York: Routledge. 
(2011) Russia and Europe: Whose Society? Journal of European Integration 33(2): 197-214.

(2012) The problem of 'the international' in Russian identity formation. International Politics 49(4): 449-465.

- (2015) Frontline Ukraine. Crisis in the Borderlands. London: I.B. Tauris.

Sanaei, M. (2013) Iran-Russia: Maintaining bilateral relations. Valdai Club, 15 April 2013, http://valdaiclub.com/asia/57440.html, accessed 16 October 2013.

Sarukhanyan, S. (2006) Rossia i Iran. 10 let yaderonovo sotrudnitshestva. Noravank. Russia and Iran. 10 years of nuclear cooperation. Yerevan: Nautshno-obrasovatelnij fond.

Sazhin, V. (2010) What kind of Iran is advantageous to Russia? Vremya Novostey, 5 March 2010.

Sheridan, M. B. (2009) Russia Not Budging on Iran Sanctions. The Washington Post, 14 October 2009, http://articles.washingtonpost.com/2009-10-

14/world/36795978_1_sanctions-and-threats-secret-nuclear-facility-iranian-nuclearprogram, accessed 19 October 2013.

UN (2006) Provisional Summary, 5612 ${ }^{\text {th }}$ Security Council Meeting, S/PV.5612, http://www.un.org/en/ga/search/view_doc.asp?symbol=S/PV.5612, accessed 13 October 2014.

(2007) Provisional Summary, 5647 ${ }^{\text {th }}$ Security Council Meeting. S/PV.5647, http://www.un.org/en/ga/search/view_doc.asp?symbol=S/PV.5647, accessed 13 October 2014.

(2010) Provisional Summary, $6335^{\text {th }}$ Security Council Meeting. S/PV. 6335, http://www.un.org/en/ga/search/view_doc.asp?symbol=S/PV.6335, accessed 13 October 2014.

Yurtaev, V. (2005) Bushehr. Russia and Iran's Meeting point. Russian Analytica, 4. 